\title{
Campylobacter Phage Isolation and Characterization: What We Have Learned So Far
}

\author{
Claudia Jäckel ${ }^{\dagger}$, Jens Andre Hammerl ${ }^{+}$(D) and Stefan Hertwig * \\ Department of Biological Safety, German Federal Institute for Risk Assessment, Max-Dohrn Str. 8-10, \\ 10589 Berlin, Germany; claudia.jaeckel@bfr.bund.de (C.J.); jens-andre.hammerl@bfr.bund.de (J.A.H.) \\ * Correspondence: stefan.hertwig@bfr.bund.de; Tel.: +49-30-18412-2019 \\ + Both authors contributed equally to this work.
}

Received: 4 January 2019; Accepted: 6 February 2019; Published: 15 February 2019

\begin{abstract}
Lytic Campylobacter phages, which can be used to combat this pathogen in animals and on food products, have been studied for more than 30 years. Though, due to some peculiarities of the phages, which hampered their isolation and particularly their molecular analysis for a long time, progress in this research field was rather slow. Meanwhile, the situation has changed and much more is known about the biology and genetics of those phages. In this article, we address specific issues that should be considered when Campylobacter phages are studied, starting with the isolation and propagation of the phages and ending with a thorough characterization including whole-genome sequencing. The basis for advice and recommendations given here is a careful review of the scientific literature and experiences that we have had ourselves with Campylobacter phages.
\end{abstract}

Keywords: Campylobacter; bacteriophage (phage); isolation; genome; propagation; sequencing; host range

\section{Introduction}

Campylobacteriosis is one of the most frequently reported foodborne illnesses in humans [1]. The disease is primarily caused by the thermophilic species Campylobacter jejuni and Campylobacter coli [2]. Typical symptoms of campylobacteriosis are diarrhea, cramping, abdominal pain, and fever [3]. Human infections are caused mainly by the handling, preparation, and consumption of undercooked meats, especially poultry [4]. Campylobacter is a commensal of the gastrointestinal tract of various mammals and birds and is frequently found in chicken flocks $[5,6]$. The prevalence of Campylobacter-positive chicken is generally high and transmission of the bacteria from bird to bird occurs rapidly [7]. Fifty to eighty percent of human infections are thought to be associated with chicken farming. Thus, reduction of Campylobacter in chicken could decrease the number of human campylobacteriosis significantly $[8,9]$.

To reduce the number of Campylobacter along the food chain, various biosecurity measures and post-slaughter decontamination procedures have been investigated, e.g., the minimization of environmental exposure (fly nets, change of footwear), the addition of organic acids to drinking water, and the chemical or physical decontamination of carcasses [10]. However, some of these measures are expensive and not always efficient [11]. Since there is not yet any vaccine available on the market to reduce the intestinal colonization of broilers by Campylobacter [12], phages that have in the past been used for typing might be an appropriate means to combat this pathogen in chicken and chicken products $[9,11,13-21]$. Phage administration in the laboratory reduced C. jejuni colonization of the broiler gut and the contamination on chicken skin by several orders of magnitude $[14,15,22-27]$. Moreover, a phage cocktail applied via drinking water also efficiently reduced Campylobacter counts in chicken on a commercial broiler farm [28]. However, since Campylobacter does not grow below $31^{\circ} \mathrm{C}$, a 
reduction of the pathogen at low temperatures can only be achieved by very high numbers of phages causing lysis from without [16,25].

Almost all Campylobacter phages described so far are lytic and belong to the family Myoviridae [29]. There are some older reports on siphoviruses infecting Campylobacter, but little information on these phages is available [30,31]. According to their genome size and morphology, lytic Campylobacter phages have been divided into three groups [21]. Group I contains phages with large genomes $(\sim 320-425 \mathrm{~kb})$ that seem to be rare $[14,21]$. They have significantly larger head dimensions than phages of the other groups [21] but have not yet been described in detail or used for applications. Moreover, to date no group I Campylobacter phage has been sequenced. However, due to their differences from group II and III phages, methods developed for the isolation of these groups may not be suited for group I. Thus, group I phages may be more common than expected. By contrast, members of group II $(\sim 175-183 \mathrm{~kb})$ and group III $(\sim 131-135 \mathrm{~kb})$ have been frequently isolated in many countries [21,29]. Common to group II and group III phages are a low burst size [15,23,32], a very low GC content of 26 to $27 \%$, and an insensitivity to cleavage by many restriction endonucleases [33-35]. These properties hampered the quick identification of group II and group III phages and the molecular characterization of these phages for many years $[21,22,36,37]$. Up to now, three group II (CP21, CP220, and CPt10) [37,38] and eight group III (CP81, CP30A, NCTC12673, PC14, PC5, vB_CjeM_Los1, CPX (CPX (NC_016562): [39]), and CP8) phages have been completely sequenced [34,40-43], whereas the genome of group II phage vB_CcoM-IBB_35 could only partially been determined (Table 1) [44]. Phages within each group revealed strong DNA homologies. Meanwhile, only weak similarities were found to exist between group II and group III phages, for which two new genera, "Cp220likevirus" (later renamed to CP220virus [45]) and "Cp8unalikevirus" (later renamed to CP8virus [45]), respectively, have been proposed. Both groups are distantly related to T4-like phages. While group III phages possess colinear genomes, those of group II phages are composed of large modules separated by long DNA repeat regions, which could lead to rearrangements [29,33]. Thus far, two subgroups of group II phages exhibiting a different modular genome organization and host range have been identified by PCR and sequencing $[38,46]$. A striking feature of group II phages is that they frequently infect both C. jejuni and C. coli [21]. However, phages of group III often lyse more C. jejuni strains than group II phages and may exhibit a stronger lytic activity $[15,37,46]$. The successive application of a group III and a group II phage reduced the numbers of $C$. jejuni in chickens most efficiently [15]. Therefore, a broad selection of well-characterized phages should be available for the reduction of Campylobacter in animals and food products.

Due to the fact that working with Campylobacter phages is a challenging task which may cause problems, we want to address a number of critical steps and give some advice how problems could be avoided or solved. Some aspects important for Campylobacter phage research and application have already been discussed by others [47-49]. These papers provide some general information and protocols on the isolation, propagation, and characterization (i.e., host range determination, protein profiling, receptor type identification, Pulsed-Field Gel Electrophoresis) of Campylobacter phages as well as on the use of the phages in live birds and food. Due to new insights into this subject and experiences in our laboratory, this article gives additional information on what should be noted and reviews some issues, which have not yet been considered (e.g., propagation of the phages in liquid cultures, strategies for the isolation and sequencing of the phage DNA). 
Table 1. Some characteristics of hitherto sequenced Campylobacter phages.

\begin{tabular}{|c|c|c|c|c|c|c|c|c|c|c|c|c|}
\hline \multirow{2}{*}{$\begin{array}{c}\text { Phage Group } \\
\text { Phage }\end{array}$} & \multicolumn{4}{|c|}{ CP220virus (Group II) } & \multicolumn{8}{|c|}{ CP8virus (Group III) } \\
\hline & СР220 & CPt10 & СР21 & IBB_35 & CP81 & $\begin{array}{l}\text { NCTC } \\
12673\end{array}$ & CPX & CP8 & CP30A & PC5 & PC14 & vB_CjeM_Los1 \\
\hline Source & Chicken & $\begin{array}{l}\text { Environ- } \\
\text { ment }\end{array}$ & $\begin{array}{c}\text { Water, } \\
\text { organic } \\
\text { farm }\end{array}$ & Poultry ceca & $\begin{array}{l}\text { Chicken } \\
\text { skin }\end{array}$ & $\begin{array}{l}\text { Poultry } \\
\text { excreta }\end{array}$ & $\begin{array}{l}\text { Retail } \\
\text { chicken }\end{array}$ & $\begin{array}{c}\text { Chicken } \\
\text { ceca }\end{array}$ & $\begin{array}{l}\text { Poultry } \\
\text { excreta }\end{array}$ & $\begin{array}{l}\text { Chicken } \\
\text { ceca }\end{array}$ & $\begin{array}{c}\text { Chicken } \\
\text { ceca }\end{array}$ & $\begin{array}{l}\text { Poultry } \\
\text { excreta }\end{array}$ \\
\hline Year of isolation & 2003 & 1989 & 2011 & n.a. & $2008 / 2009$ & $\begin{array}{l}\text { Before } \\
1985\end{array}$ & n.a. & n.a. & n.a. & $2011 / 2012$ & $2011 / 2012$ & n.a. \\
\hline Country & $\begin{array}{l}\text { United } \\
\text { Kingdom }\end{array}$ & $\begin{array}{l}\text { United } \\
\text { Kingdom }\end{array}$ & Germany & Portugal & Germany & USA & $\begin{array}{l}\text { United } \\
\text { Kingdom }\end{array}$ & $\begin{array}{l}\text { United } \\
\text { Kingdom }\end{array}$ & $\begin{array}{l}\text { United } \\
\text { Kingdom }\end{array}$ & Slovenia & Slovenia & Ireland \\
\hline Family & $\begin{array}{c}\text { Myo- } \\
\text { viridae }\end{array}$ & $\begin{array}{c}\text { Myo- } \\
\text { viridae }\end{array}$ & $\begin{array}{c}\text { Myo- } \\
\text { viridae }\end{array}$ & $\begin{array}{c}\text { Myo- } \\
\text { viridae }\end{array}$ & $\begin{array}{c}\text { Myo- } \\
\text { viridae }\end{array}$ & $\begin{array}{c}\text { Myo- } \\
\text { viridae }\end{array}$ & $\begin{array}{c}\text { Myo- } \\
\text { viridae }\end{array}$ & $\begin{array}{c}\text { Myo- } \\
\text { viridae }\end{array}$ & $\begin{array}{c}\text { Myo- } \\
\text { viridae }\end{array}$ & Myo-viridae & $\begin{array}{c}\text { Myo- } \\
\text { viridae }\end{array}$ & $\begin{array}{c}\text { Myo- } \\
\text { viridae }\end{array}$ \\
\hline Host range & $\begin{array}{l}\text { C. jejuni, } \\
\text { C. coli }\end{array}$ & $\begin{array}{l}\text { C. jejuni, } \\
\text { C. coli }\end{array}$ & $\begin{array}{l}\text { C. jejuni, } \\
\text { C. coli }\end{array}$ & $\begin{array}{l}\text { C. jejuni, } \\
\text { C. coli }\end{array}$ & C. jejuni & C. jejuni & C. jejuni & C. jejuni & C. jejuni & C. jejuni & C. jejuni & C. jejuni \\
\hline Restriction & Refractory & Refractory & Refractory & Refractory & Refractory & Refractory & Refractory & Refractory & Refractory & Refractory & Refractory & n.a. \\
\hline $\begin{array}{l}\text { Sequencing/ } \\
\text { platform }\end{array}$ & $\begin{array}{l}\text { Shotgun } \\
\text { seq. DNA } \\
\text { libraries }\end{array}$ & $\begin{array}{l}454 \text { FLX } \\
\text { pyroseq. } \\
\text { and PCR/ } \\
\text { Sanger }\end{array}$ & $\begin{array}{l}454 \text { FLX } \\
\text { pyroseq., } \\
\text { and PCR/ } \\
\text { Sanger }\end{array}$ & $\begin{array}{l}454 \text { FLX } \\
\text { pyroseq. }\end{array}$ & $\begin{array}{l}454 \text { FLX } \\
\text { pyroseq. }\end{array}$ & $\begin{array}{l}\text { Fidelity } \\
\text { System }\end{array}$ & $\begin{array}{l}454 \text { FLX } \\
\text { pyroseq. }\end{array}$ & n.a. & $\begin{array}{l}454 \text { FLX } \\
\text { pyroseq. }\end{array}$ & $\begin{array}{l}454 \text { FLX } \\
\text { pyroseq. }\end{array}$ & $\begin{array}{l}454 \text { FLX } \\
\text { pyroseq. }\end{array}$ & Illumina \\
\hline $\begin{array}{c}\text { Genome size } \\
\text { (bp) }\end{array}$ & 177,493 & 175,720 & 182,833 & 172,065 & 132,454 & 135,041 & 132,662 & 132,667 & 133,572 & 131,095 & 134,927 & 134,073 \\
\hline $\begin{array}{l}\text { Complex repeat } \\
\text { regions }\end{array}$ & + & + & + & n.a. & - & - & - & - & - & - & - & - \\
\hline GC content $(\%)$ & 27.4 & 27.3 & 27.2 & 27.4 & 26.1 & 26.2 & 26.0 & 26.0 & 26.1 & 26.1 & 26.2 & 26.2 \\
\hline PFGE size (kb) & $\sim 197$ & n.a. & $\sim 209$ & $\sim 204$ & $\sim 145$ & $\sim 170$ & n.a. & $\sim 140$ & n. a. & $\sim 150$ & $\sim 150$ & n.a. \\
\hline $\begin{array}{l}\text { Accession no. } \\
\text { Reference }\end{array}$ & $\begin{array}{c}\text { FN667788 } \\
{[37]}\end{array}$ & $\begin{array}{c}\text { FN667789 } \\
{[37]}\end{array}$ & $\begin{array}{c}\text { NC019507 } \\
{[38,46]}\end{array}$ & $\begin{array}{c}\text { HM246720-4 } \\
{[44]}\end{array}$ & $\begin{array}{c}\text { FR823450 } \\
{[34]}\end{array}$ & $\begin{array}{c}\text { NC015464 } \\
{[41]}\end{array}$ & $\begin{array}{c}\text { NC016562.1 } \\
\text { n.a. }\end{array}$ & $\begin{array}{c}\text { KF148616 } \\
{[43]}\end{array}$ & $\begin{array}{c}\text { NC018861 } \\
{[40]}\end{array}$ & $\begin{array}{c}\text { KX229736 } \\
{[42]}\end{array}$ & $\begin{array}{c}\mathrm{KX} 236333 \\
{[42]}\end{array}$ & $\begin{array}{c}\text { KX879627 } \\
{[43]}\end{array}$ \\
\hline
\end{tabular}




\section{Isolation of Campylobacter Phages}

Sampling: Campylobacter phages are normally found in all places at which their hosts occur [50]. They have been isolated from poultry (i.e., meat, liver, skin, feces, and intestines), manure, and sewage [22,36,43,50-52]. High rates of Campylobacter phages have been isolated from organic farms [53]. Samples intended to be used for phage isolation should not be frozen because this treatment may reduce the plaque-forming ability significantly (by up to 80\%) [22,54]. While Campylobacter phages were isolated at a rate of $11 \%(34 / 300)$ from the skin of fresh chicken thighs, isolation from frozen chicken thighs was unsuccessful [22,55]. Even though polymerase chain reaction (PCR) analysis revealed the presence of Campylobacter phages in many frozen food samples, most of the detected phages did not show any lytic activity [54]. Some Campylobacter phages seem to be unstable and could not be successfully propagated after isolation [56]. Therefore, rough treatments (e.g., extensive vortexing) should be avoided.

Sample preparation: Solid sample material can be incubated in Sodium chloride/Magnesium sulfate (SM)-buffer to resuspend phages. On chicken skin, Campylobacter phages are able to adhere very tightly. They can be removed by rinsing and swabbing but the use of a Stomacher ${ }^{\circledR}$ (i.e. BagMixer ${ }^{\circledR}$, Interscience, Saint Nom, France) may give the best results. After centrifugation $(10,000 \times g, 20-60 \mathrm{~min})$ of the material and subsequent filtration $(0.45 \mu \mathrm{m}$ and $0.22 \mu \mathrm{m})$ of the supernatant, samples can be examined for lytic activity. A 10-fold concentration of phage preparations prior to spotting on indicator strains can be achieved by centrifugal filter units (i.e., Amicon ${ }^{\circledR}$ Ultra Centrifugal Filters, Merck KGaA, Darmstadt, Germany, Vivaspin ${ }^{\circledR}$, Sartorius, Göttingen, Germany).

(Pre-)screening for Campylobacter phages by PCR: PCR may be useful to pre-screen samples and to detect and discriminate group II and group III phages quickly. We applied the method to detect Campylobacter phages in various meat products and samples collected from chicken and pig farms. In 50 out of 110 samples (45.5\%), group II and/or group III phages were identified. PCR-positive samples which do not show lytic activity on common indicator strains can then be examined with other strains that may be suitable hosts for the phage [54]. On the other hand, PCR-negative samples may contain unusual (e.g., group I) Campylobacter phages and should also be examined for lytic activity.

Selection of indicator strains: Campylobacter jejuni NCTC12662 (PT14) is often used for testing because it is susceptible to a wide range of phages $[35,50,57,58]$. Nevertheless, it is recommendable to study a broad range of strains representing several fla-types and Penner serotypes since group II and group III phages bind to different cell receptors, the flagellum and capsular polysaccharide, respectively [21,34,48,57-60]. It is conceivable that the fact that such similar Campylobacter phages have been isolated it is, inter alia, caused by the selection of the same indicator strains. A protocol is available to determine the receptor dependency of Campylobacter phages [48].

Cultivation of indicator strains: Cultures of indicator strains should be created in flasks rather than tubes, as growth of Campylobacter is enhanced by a large surface for gas exchange. While different media (e.g., Mueller-Hinton, Brain Heart Infusion, Brucella broth) can be used to cultivate Campylobacter [61], the right choice of overlay (soft agar) is important for the outcome of activity tests. The agar should contain $\mathrm{CaCl}_{2}$ and $\mathrm{MgSO}_{4}$, which are thought to facilitate the attachment of phages to their host cell, even though in some cases the addition of divalent cations may be counter-productive. As did other groups, we obtained a dense and even lawn of Campylobacter on NZCYM agar [21,62,63]. By contrast, e.g., lysogeny broth (LB) is less suited for this application because of an uneven and slimy growth of bacteria, which impedes the detection of plaques.

Determination of lytic activity: The lytic activity of phages can not only be determined by plaque assays but also by a microplate test that allows the rapid, cheaper, and less time-consuming identification of susceptible Campylobacter strains [64]. However, cross-contamination of strains and/or phages may be enhanced by this method. Upon the detection of lytic activity, dilutions of phage preparations can be plated to obtain single plaques. Plaques produced by lytic Campylobacter phages are typically small ( $1 \mathrm{~mm}$ in diameter) and slightly turbid. Since inhibition zones in the bacterial lawn can also be caused by other substances, e.g., bacteriocins [53], a zoom stereo microscope may be 
helpful to detect and count plaques. Individual phages should then be recovered by three consecutive single plaque isolations $[34,46]$.

\section{Propagation, Concentration, and Purification of the Phages}

Propagation: The propagation of lytic phages is generally performed by the production of agar plates exhibiting confluent lysis or by the infection of bacterial cultures [63]. Both methods can be used for Campylobacter phages but they are not similarly suited for all phages [34,46-48]. Thus, for each phage the optimal procedure should be determined. Phage propagation in liquid cultures is somewhat more demanding because the growth phase of the bacteria at which phages are added and the MOI (multiplicity of infection) have to be determined to obtain maximal phage titers [63]. In our laboratory we mostly achieved the best results $\left(>10^{8} \mathrm{pfu} / \mathrm{mL}\right)$ by infecting $100-\mathrm{mL}$ cultures of the indicator strain $\left(\mathrm{OD}_{588}\right.$ of $\sim 0.4$ ) with phages at an MOI of $\sim 0.01$ followed by incubation for $12-24 \mathrm{~h}$ at $42{ }^{\circ} \mathrm{C}[15,34,38,46]$. Very long incubation periods may give lower titers due to the binding of phages to cell debris [65]. Although Campylobacter is a microaerophile, it grows well under soft shaking (100 rpm) in a cell culture flask with a filter cap placed in a box containing a gas-generating sachet to approximate optimal growth conditions $\left(10 \% \mathrm{CO}_{2}, 5 \% \mathrm{O}_{2}, 85 \% \mathrm{~N}_{2}\right)$. This approach has the advantage that the mass lysate does not contain any contaminating agar, which may aggravate filtration. However, a procedure has been described in which soft-agar is not harvested but overlaid with buffer that is removed from the plates after incubation overnight $[36,47,50]$.

Concentration: After the removal of the remaining cells, debris, and, if necessary, agar by centrifugation $(10,000 \times g, 20 \mathrm{~min})$, the lysate is filtrated $(0.45$ and $0.22 \mu \mathrm{m})$. To degrade bacterial DNA and RNA, $20 \mathrm{mg} / \mathrm{mL}$ DNase and RNase should be added to the lysate, which should be incubated for 30 to $60 \mathrm{~min}$ at $37^{\circ} \mathrm{C}$. Thereafter, phage particles can be concentrated by ammonium acetate purification [66], ultracentrifugation, polyethylene glycol (PEG) precipitation, tangential filtration, or the use of centrifugal concentrators (i.e., Vivaspin ${ }^{\circledR}$, Sartorius, Göttingen, Germany, Nanosep Centrifugal Devices ${ }^{\circledR}$, Pall Corporation, New York, USA) depending on the volume of the lysate and the available technological equipment $[34,36,46,50]$. We mostly prefer concentration by an ultracentrifuge using a rotor for six tubes that each can be filled with approximately $100 \mathrm{~mL}$ lysate. After centrifugation for 2 hours $(100,000$ to $200,000 \times g)$ at $10{ }^{\circ} \mathrm{C}$, almost all phage particles are sedimented and the pellet can be resuspended in 1-2 mL of SM-buffer. PEG precipitation is a cheap and simple method to harvest phages, which is suited for large volumes [63]. However, pellets obtained by the centrifugation of precipitated particles are rather dirty and may cause problems during the purification of phages by density gradient centrifugation. Commercial centrifugal concentrators are also simple in use but are mainly suited for small volumes (less than $100 \mathrm{~mL}$ ) as the membrane is rather quickly blocked by phage particles and other ingredients of the lysate (e.g., agar remnants), which may pollute the retentate.

Purification and electron microscopic analysis: For the purification of Campylobacter phages by $\mathrm{CsCl}_{2}$ density gradient centrifugation, standard protocols can be used. To obtain a clearly visible phage band, at least $10^{9}$ infectious particles should be applied. After pulling out the phage band with a syringe, cesium chloride can be removed by dialysis or by the use of centrifugal filter units. Thereafter, the preparation can be utilized for various studies, e.g., the determination of the morphology of the phages by electron microscopy, the host range, or the analysis of the phage genome and structural proteins. Electron micrographs are usually taken from virions negatively stained with uranyl acetate. However, to determine the exact size of particles and to visualize detailed structures of the phages, staining with phosphotungstate, sodium silicotungstate, or ammonium molybdate may be advisable [29,34,35]. Campylobacter phages can be classified according their morphology, but since group II and group III phages have similar outlines and dimensions, discrimination necessitates high-quality electron micrographs [29]. 


\section{Isolation and Analysis of Campylobacter Phage DNA}

DNA extraction: All Campylobacter phages that have yet been sequenced possess double-stranded DNA $[29,33]$. However, there is a striking difference between the DNA of group II and group III phages, which should be taken into account when phage DNA is prepared [34,46]. While the standard protocol [63], which includes phenol-chloroform extractions, is suitable for the isolation of group II phage DNA, it fails with the DNA of group III phages because of the unusual behavior of the DNA-it remains associated with the interphase, possibly caused by tightly bound protein $[29,34,46]$. Therefore, phenol-chloroform extractions should be omitted when the DNA of group III phages is isolated. In this case, it is recommendable to digest the phage preparation with proteinase $\mathrm{K}$ and sodium dodecyl sulfate (SDS) followed by the precipitation of the DNA with alcohol [34]. Alternatively, commercially available phage DNA isolation kits can be used. The quantification of Campylobacter phage DNA by spectrophotometric methods may give inaccurate results [41].

Restriction analysis and PFGE: Campylobacter phage DNA is highly resistant against digestion by many restriction endonucleases (i.e., AvaII, BamHI, ClaI, EcoRI, EcoRV, HaeIII, HindIII, HinfI, HpaII, PstI, PvuI RsaI, ScaI) [21]. To roughly determine the genome size of the phages and to allocate them to groups and subgroups, PFGE analyses were performed using the restriction enzyme HhaI, for which a detailed protocol has been published [48]. HhaI recognizes the site $5^{\prime}$-GCGC-3' but cleaves Campylobacter phage DNA only rarely [35]. The DNA of Campylobacter phages is hardly cleaved by enzymes whose recognition sites contain the bases cytosine and guanine because of a yet unknown modification of the DNA. By contrast, restriction endonucleases, which recognize sheer A/T sequences (e.g., DraI, SmiI, VspI) can be used to cut the phage DNA and to compare restriction patterns on standard agarose gels allowing a cost-efficient and time-saving analysis [34,36].

Phage DNA amplification: It has been reported that Campylobacter phage DNA was refractory to PCR amplification [37]. However, using the DreamTaq DNA polymerase amplification components (Thermo Fisher Scientific, Waltham, Massachusetts, USA), we never faced this problem, neither with group II nor with group III phages. To amplify the long repeat regions of group II phages for sequencing, primers up to 40 nucleotides in length were used. The genomes of Campylobacter phages can also be amplified with a whole-genome amplification kit yielding high amounts of DNA that can be used for further studies (e.g., restriction analyses, DNA-DNA hybridization, PCR) [34].

Genome sequencing: The sequencing of Campylobacter phage genomes is a challenging task. Besides modifications of the DNA, which can impede PCR reactions, the low G + C content $(\sim 27 \%)$ and extensive repetitive sequences complicate whole-genome sequencing. Thus, due to substances that inhibited Taq and $\$ 29$ polymerases, only five contigs of the genome of group II phage vB_CcoM-IBB_35 could be obtained [44]. To date, all Campylobacter phage genomes have been sequenced by short-read sequencing, which is prone to homopolymer errors. In addition, long DNA repeats, as they occur in group II phages, obstruct the assembly of reads. To sequence the repeats of phage CP21, the respective regions were amplified by PCR and used as targets for in vitro transposon mutagenesis. Upon the molecular cloning of the marked PCR products in Escherichia coli, transformants with transposon insertions at different positions within each repeat were sequenced to determine the whole sequences of the regions [46]. Long-read sequencing (i.e., PacBio, MinION) can solve some problems but often requires high amounts of DNA $(2-10 \mu \mathrm{g})$, which cannot be easily prepared from Campylobacter phages. The use of a whole-genome amplification kit may provide enough DNA but the amplified DNA usually contains some nucleotide exchanges and is therefore not equivalent to native DNA [34].

\section{Studies Important for the Application of Campylobacter Phages}

Phages intended to be used for the control of pathogens have to fulfill a number of requirements [34]. Phage genomes, for example, have to be free from undesired genes, e.g., genes encoding toxins. Although many gene products of the hitherto sequenced Campylobacter phages could not be functionally assigned, virulence-associated genes have not been detected on their genomes [34,40-43]. The genomes are linear, circularly permuted molecules. It cannot be excluded 
that the phages are able to transduce DNA, but this has yet to be examined. To harness phages they should be stable against a wide range of $\mathrm{pH}$ values and temperatures [26]. A broad host range is another important prerequisite for successful application. As mentioned above, group II and group III phages diverge in terms of their host specificity $[21,29,33]$. In addition, the kinetics of infection may be different. For that reason, phage cocktails should contain members of both groups to aim at C. jejuni and C. coli, to optimize the application strategy and to prevent phage resistance. Moreover, phages within each group may differ in their host range and lytic activity, even though they are genetically very similar. Group II phages, e.g., could be allocated to two subgroups, one of which lysed nearly twice as many strains than the other [46]. A comparison of group III phages revealed that one phage reduced the number of Campylobacter in vitro significantly more strongly than the remaining phages and was therefore chosen for an animal experiment [15]. This and other studies also showed that individual Campylobacter phages may induce different rates of resistance. The reason for this phenomenon is not only the fact that group II and group III phages use different host cell receptors. Even within each group, resistance rates may vary. Therefore, a number of Campylobacter phages and a wide spectrum of strains covering various Penner serotypes and fla-types should be examined to find the best phage candidates for applications. It must, however, be taken into account that data that have been collected in vitro cannot simply be transferred to real conditions (e.g., the gut of a chicken) where physicochemical factors and the resident microflora may influence the outcome of the application.

\section{Conclusions}

Campylobacter is an important foodborne pathogen which can be reduced along the food chain by the application of lytic phages. To create efficient and safe Campylobacter phage cocktails, methods are needed to isolate, propagate, and purify new phages for further analyses. Compared with most other lytic phages, Campylobacter phages exhibit some characteristics which make their application rather difficult. However, many problems that we have faced in the past could be solved by intensive studies on these phages. Thus, protocols are now available which allow the quick detection, isolation, and characterization of Campylobacter phages $[47,48]$. The main steps of this procedure are outlined in Figure 1. Nevertheless, the question arises as to why, up to now, very similar phages have been described and whether other Campylobacter phages exist in nature, which may possess novel properties and could be harnessed for applications. This question can now be answered more easily since a lot more information is available on the biology and genetics of these interesting phages. 


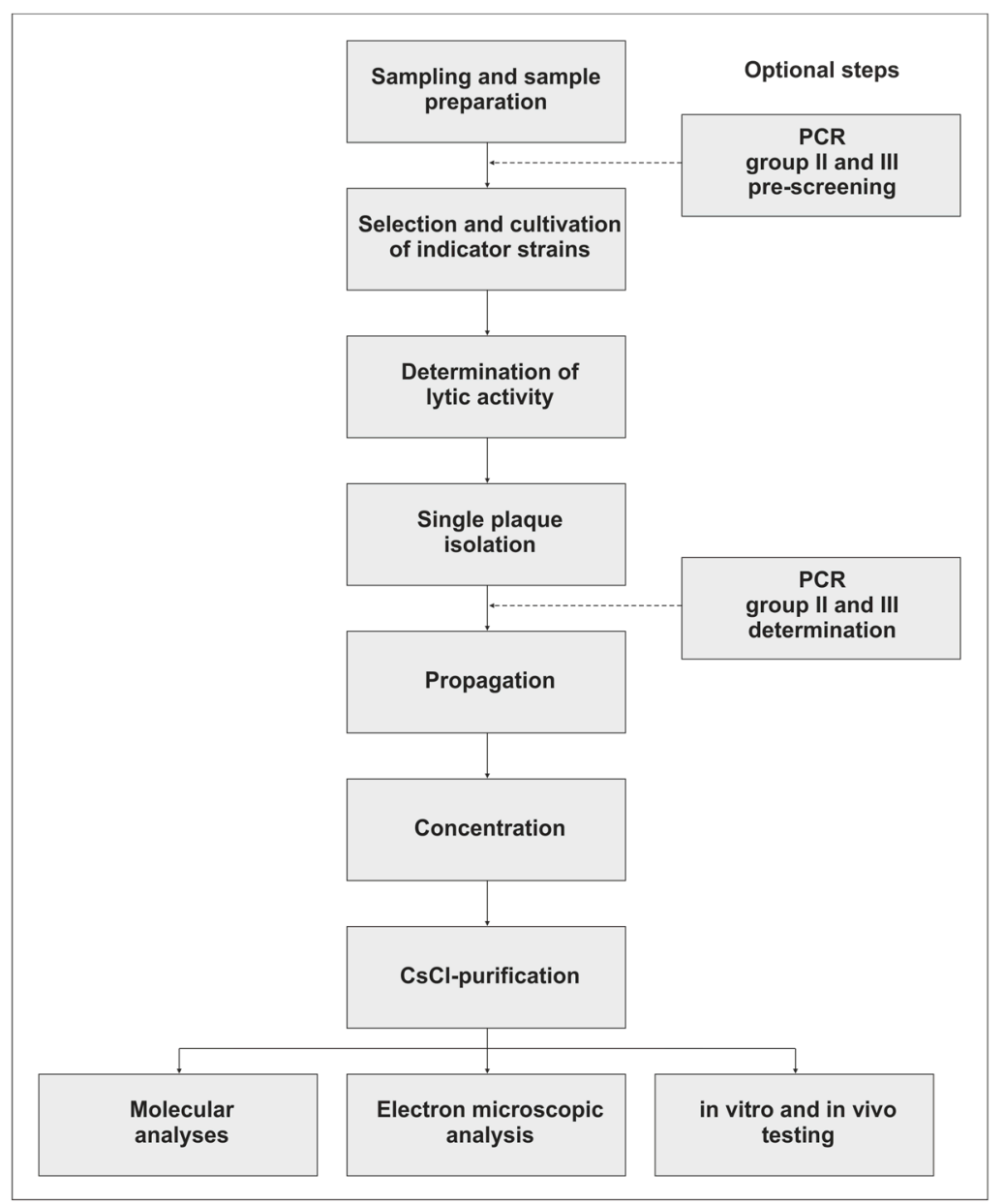

Figure 1. Flowchart of Campylobacter phage isolation, propagation, purification, and analysis. PCR: Polymerase chain reaction.

Author Contributions: S.H., J.A.H., and C.J. summarized the data and wrote the paper.

Acknowledgments: The authors thank Torsten Winn, Charlotte Tonar, Katharina Bratz, Alexandra Irrgang, and Barbara Freytag of the BfR for their initial work on Campylobacter phages.

Conflicts of Interest: The authors declare no conflict of interest. The founding sponsors had no role in the design of the study; in the collection, analyses, or interpretation of data; in the writing of the manuscript, and in the decision to publish the results.

\section{References}

1. European Centre for Disease Prevention and Control (ECDC). Annual Epidemiological Report 2012: Annual Epidemiological Report Reporting on 2010 Surveillance Data and 2011 Epidemic Intelligence Data; ECDC: Solna Stad, Sweden, 2013.

2. Moore, J.E.; Corcoran, D.; Dooley, J.S.; Fanning, S.; Lucey, B.; Matsuda, M.; McDowell, D.A.; Megraud, F.; Millar, B.C.; O'Mahony, R.; et al. Campylobacter. Vet. Res. 2005, 36, 351-382. [CrossRef] [PubMed]

3. O'Brien, S.J. The Consequences of Campylobacter Infection. Curr. Opin. Gastroenterol. 2017, 33, 14-20. [CrossRef] [PubMed]

4. Shane, S.M. Campylobacter Infection of Commercial Poultry. Rev. Sci. Tech. 2000, 19, 376-395. [CrossRef] [PubMed]

5. Blaser, M.J.; LaForce, F.M.; Wilson, N.A.; Wang, W.L. Reservoirs for Human Campylobacteriosis. J. Infect. Dis. 1980, 141, 665-669. [CrossRef] [PubMed]

6. Humphrey, T.; O’Brien, S.; Madsen, M. Campylobacters as Zoonotic Pathogens: A Food Production Perspective. Int. J. Food Microbiol. 2007, 117, 237-257. [CrossRef] [PubMed] 
7. Lee, M.D.; Newell, D.G. Campylobacter in Poultry: Filling an Ecological Niche. Avian Dis. 2006, 50, 1-9. [CrossRef] [PubMed]

8. $\quad$ Rosenquist, H.; Nielsen, N.L.; Sommer, H.M.; Norrung, B.; Christensen, B.B. Quantitative Risk Assessment of Human Campylobacteriosis Associated with Thermophilic Campylobacter Species in Chickens. Int. J. Food Microbiol. 2003, 83, 87-103. [CrossRef]

9. Havelaar, A.H.; Mangen, M.J.; de Koeijer, A.A.; Bogaardt, M.J.; Evers, E.G.; Jacobs-Reitsma, W.F.; van Pelt, W.; Wagenaar, J.A.; de Wit, G.A.; van der Zee, H.; et al. Effectiveness and Efficiency of Controlling Campylobacter on Broiler Chicken Meat. Risk Anal. 2007, 27, 831-844. [CrossRef]

10. Klein, G.; Jansen, W.; Kittler, S.; Reich, F. Mitigation Strategies for Campylobacter spp. in Broiler at Pre-Harvest and Harvest Level. Berl. Münch. Tierärztl. Wochenschr. 2015, 128, 132-140.

11. Umaraw, P.; Prajapati, A.; Verma, K.; Pathak, V.; Singh, V.P. Control of Campylobacter in Poultry Industry from Farm to Poultry Processing Unit: A Review. Crit. Rev. Food Sci. Nutr. 2017, 57, 659-665. [CrossRef]

12. Meunier, M.; Guyard-Nicodeme, M.; Hirchaud, E.; Parra, A.; Chemaly, M.; Dory, D. Identification of Novel Vaccine Candidates against Campylobacter through Reverse Vaccinology. J. Immunol. Res. 2016, 2016, 5715790. [CrossRef] [PubMed]

13. Meunier, M.; Guyard-Nicodeme, M.; Dory, D.; Chemaly, M. Control Strategies against Campylobacter at the Poultry Production Level: Biosecurity Measures, Feed Additives and Vaccination. J. Appl. Microbiol. 2016, 120, 1139-1173. [CrossRef] [PubMed]

14. El-Shibiny, A.; Scott, A.; Timms, A.; Metawea, Y.; Connerton, P.; Connerton, I. Application of a Group II Campylobacter Bacteriophage to Reduce Strains of Campylobacter jejuni and Campylobacter coli Colonizing Broiler Chickens. J. Food Prot. 2009, 72, 733-740. [CrossRef] [PubMed]

15. Hammerl, J.A.; Jäckel, C.; Alter, T.; Janzcyk, P.; Stingl, K.; Knüver, M.T.; Hertwig, S. Reduction of Campylobacter jejuni in Broiler Chicken by Successive Application of Group II and Group III Phages. PLoS ONE 2014, 9, e114785. [CrossRef]

16. Orquera, S.; Gölz, G.; Hertwig, S.; Hammerl, J.A.; Sparborth, D.; Joldic, A.; Alter, T. Control of Campylobacter spp. And Yersinia enterocolitica by Virulent Bacteriophages. J. Mol. Genet. Med. 2012, 6, 273-278. [CrossRef] [PubMed]

17. Gibson, J.R.; Fitzgerald, C.; Owen, R.J. Comparison of PFGE, Ribotyping and Phage-Typing in the Epidemiological Analysis of Campylobacter jejuni Serotype HS2 Infections. Epidemiol. Infect. 1995, 115, 215-225. [CrossRef] [PubMed]

18. Grajewski, B.A.; Kusek, J.W.; Gelfand, H.M. Development of a Bacteriophage Typing System for Campylobacter jejuni and Campylobacter coli. J. Clin. Microbiol. 1985, 22, 13-18. [PubMed]

19. Hopkins, K.L.; Desai, M.; Frost, J.A.; Stanley, J.; Logan, J.M. Fluorescent Amplified Fragment Length Polymorphism Genotyping of Campylobacter jejuni and Campylobacter coli Strains and Its Relationship with Host Specificity, Serotyping, and Phage Typing. J. Clin. Microbiol. 2004, 42, 229-235. [CrossRef]

20. Khakhria, R.; Lior, H. Extended Phage-Typing Scheme for Campylobacter jejuni and Campylobacter coli. Epidemiol. Infect. 1992, 108, 403-414. [CrossRef]

21. Sails, A.D.; Wareing, D.R.; Bolton, F.J.; Fox, A.J.; Curry, A. Characterisation of 16 Campylobacter jejuni and C. coli Typing Bacteriophages. J. Med. Microbiol. 1998, 47, 123-128. [CrossRef]

22. Atterbury, R.J.; Connerton, P.L.; Dodd, C.E.; Rees, C.E.; Connerton, I.F. Application of Host-Specific Bacteriophages to the Surface of Chicken Skin Leads to a Reduction in Recovery of Campylobacter jejuni. Appl. Environ. Microbiol. 2003, 69, 6302-6306. [CrossRef] [PubMed]

23. Carvalho, C.M.; Gannon, B.W.; Halfhide, D.E.; Santos, S.B.; Hayes, C.M.; Roe, J.M.; Azeredo, J. The in vivo Efficacy of Two Administration Routes of a Phage Cocktail to Reduce Numbers of Campylobacter coli and Campylobacter jejuni in Chickens. BMC Microbiol. 2010, 10, 232. [CrossRef]

24. Fischer, S.; Kittler, S.; Klein, G.; Glünder, G. Impact of a Single Phage and a Phage Cocktail Application in Broilers on Reduction of Campylobacter jejuni and Development of Resistance. PLoS ONE 2013, 8, e78543. [CrossRef] [PubMed]

25. Goode, D.; Allen, V.M.; Barrow, P.A. Reduction of Experimental Salmonella and Campylobacter Contamination of Chicken Skin by Application of Lytic Bacteriophages. Appl. Environ. Microbiol. 2003, 69, 5032-5036. [CrossRef] [PubMed] 
26. Loc Carrillo, C.; Atterbury, R.J.; El-Shibiny, A.; Connerton, P.L.; Dillon, E.; Scott, A.; Connerton, I.F. Bacteriophage Therapy to Reduce Campylobacter jejuni Colonization of Broiler Chickens. Appl. Environ. Microbiol. 2005, 71, 6554-6563. [CrossRef] [PubMed]

27. Wagenaar, J.A.; Van Bergen, M.A.; Müller, M.A.; Wassenaar, T.M.; Carlton, R.M. Phage Therapy Reduces Campylobacter jejuni Colonization in Broilers. Vet. Microbiol. 2005, 109, 275-283. [CrossRef] [PubMed]

28. Kittler, S.; Fischer, S.; Abdulmawjood, A.; Glünder, G.; Klein, G. Effect of Bacteriophage Application on Campylobacter jejuni Loads in Commercial Broiler Flocks. Appl. Environ. Microbiol. 2013, 79, 7525-7533. [CrossRef]

29. Javed, M.A.; Ackermann, H.W.; Azeredo, J.; Carvalho, C.M.; Connerton, I.; Evoy, S.; Hammerl, J.A.; Hertwig, S.; Lavigne, R.; Singh, A.; et al. A Suggested Classification for Two Groups of Campylobacter Myoviruses. Arch. Virol. 2014, 159, 181-190. [CrossRef]

30. Bryner, J.H.; Ritchie, A.E.; Booth, G.D.; Foley, J.W. Lytic Activity of Vibrio Phages on Strains of Vibrio fetus Isolated from Man and Animals. Appl. Microbiol. 1973, 26, 404-409.

31. Bryner, J.H.; Ritchie, A.E.; Foley, J.W.; Berman, D.T. Isolation and Characterization of a Bacteriophage for Vibrio fetus. J. Virol. 1970, 6, 94-99.

32. Lis, L.; Connerton, I.F. The Minor Flagellin of Campylobacter jejuni (FlaB) Confers Defensive Properties against Bacteriophage Infection. Front. Microbiol. 2016, 7, 1908. [CrossRef] [PubMed]

33. Hammerl, J.A.; Jäckel, C.; Hertwig, S. Genetics of Campylobacter Phages. Berl. Münch. Tierärztl. Wochenschr. 2015, 128, 148-154. (In German) [PubMed]

34. Hammerl, J.A.; Jäckel, C.; Reetz, J.; Beck, S.; Alter, T.; Lurz, R.; Barretto, C.; Brüssow, H.; Hertwig, S. Campylobacter jejuni Group III Phage CP81 Contains Many T4-Like Genes without Belonging to the T4-Type Phage Group: Implications for the Evolution of T4 Phages. J. Virol. 2011, 85, 8597-8605. [CrossRef] [PubMed]

35. Hansen, V.M.; Rosenquist, H.; Baggesen, D.L.; Brown, S.; Christensen, B.B. Characterization of Campylobacter Phages Including Analysis of Host Range by Selected Campylobacter Penner Serotypes. BMC Microbiol. 2007, 7, 90. [CrossRef] [PubMed]

36. Loc Carrillo, C.M.; Connerton, P.L.; Pearson, T.; Connerton, I.F. Free-Range Layer Chickens as a Source of Campylobacter Bacteriophage. Antonie Van Leeuwenhoek 2007, 92, 275-284. [CrossRef] [PubMed]

37. Timms, A.R.; Cambray-Young, J.; Scott, A.E.; Petty, N.K.; Connerton, P.L.; Clarke, L.; Seeger, K.; Quail, M.; Cummings, N.; Maskell, D.J.; et al. Evidence for a Lineage of Virulent Bacteriophages That Target Campylobacter. BMC Genom. 2010, 11, 214. [CrossRef] [PubMed]

38. Hammerl, J.A.; Jäckel, C.; Reetz, J.; Hertwig, S. The Complete Genome Sequence of Bacteriophage CP21 Reveals Modular Shuffling in Campylobacter Group II Phages. J. Virol. 2012, 86, 8896. [CrossRef]

39. Timms, A.R.; Al Khandari, S.; Wilson, R.; Rowsell, J.; Connerton, I.F. Campylobacter Phage CPX, Complete Genome. 2011; unpublished.

40. Brathwaite, K.J.; Siringan, P.; Connerton, P.L.; Connerton, I.F. Host Adaption to the Bacteriophage Carrier State of Campylobacter jejuni. Res. Microbiol. 2015, 166, 504-515. [CrossRef]

41. Kropinski, A.M.; Arutyunov, D.; Foss, M.; Cunningham, A.; Ding, W.; Singh, A.; Pavlov, A.R.; Henry, M.; Evoy, S.; Kelly, J.; et al. Genome and Proteome of Campylobacter jejuni Bacteriophage NCTC 12673. Appl. Environ. Microbiol. 2011, 77, 8265-8271. [CrossRef]

42. Janez, N.; Peterka, M.; Accetto, T. Complete Genome Sequences of Group III Campylobacter Bacteriophages PC5 and PC14. Genome Announc. 2016, 4, e01030-16. [CrossRef]

43. O'Sullivan, L.; Lucid, A.; Neve, H.; Franz, C.; Bolton, D.; McAuliffe, O.; Paul Ross, R.; Coffey, A. Comparative Genomics of CP8viruses with Special Reference to Campylobacter Phage vb_Cjem_Los1, Isolated from a Slaughterhouse in Ireland. Arch. Virol. 2018, 163, 2139-2154. [CrossRef] [PubMed]

44. Carvalho, C.M.; Kropinski, A.M.; Lingohr, E.J.; Santos, S.B.; King, J.; Azeredo, J. The Genome and Proteome of a Campylobacter coli Bacteriophage vb_Ccom-Ibb_35 Reveal Unusual Features. Virol. J. 2012, 9, 35. [CrossRef] [PubMed]

45. Adams, M.J.; Lefkowitz, E.J.; King, A.M.; Harrach, B.; Harrison, R.L.; Knowles, N.J.; Kropinski, A.M.; Krupovic, M.; Kuhn, J.H.; Mushegian, A.R.; et al. Ratification Vote on Taxonomic Proposals to the International Committee on Taxonomy of Viruses (2016). Arch. Virol. 2016, 161, 2921-2949. [CrossRef] [PubMed]

46. Jäckel, C.; Hammerl, J.A.; Reetz, J.; Kropinski, A.M.; Hertwig, S. Campylobacter Group II Phage CP21 Is the Prototype of a New Subgroup Revealing a Distinct Modular Genome Organization and Host Specificity. BMC Genom. 2015, 16, 629 . 
47. Gencay, Y.E.; Birk, T.; Sorensen, M.C.; Brondsted, L. Methods for Isolation, Purification, and Propagation of Bacteriophages of Campylobacter jejuni. Methods Mol. Biol. 2017, 1512, 19-28.

48. Sorensen, M.C.; Gencay, Y.E.; Brondsted, L. Methods for Initial Characterization of Campylobacter jejuni Bacteriophages. Methods Mol. Biol. 2017, 1512, 91-105.

49. Janez, N.; Loc-Carrillo, C. Use of Phages to Control Campylobacter spp. J. Microbiol. Methods 2013, 95, 68-75. [CrossRef]

50. Owens, J.; Barton, M.D.; Heuzenroeder, M.W. The Isolation and Characterization of Campylobacter jejuni Bacteriophages from Free Range and Indoor Poultry. Vet. Microbiol. 2013, 162, 144-150. [CrossRef]

51. Furuta, M.; Nasu, T.; Umeki, K.; Hoang Minh, D.; Honjoh, K.I.; Miyamoto, T. Characterization and Application of Lytic Bacteriophages against Campylobacter jejuni Isolated from Poultry in Japan. Biocontrol Sci. 2017, 22, 213-221. [CrossRef]

52. Firlieyanti, A.S.; Connerton, P.L.; Connerton, I.F. Campylobacters and Their Bacteriophages from Chicken Liver: The Prospect for Phage Biocontrol. Int. J. Food Microbiol. 2016, 237, 121-127. [CrossRef]

53. El-Shibiny, A.; Connerton, P.L.; Connerton, I.F. Enumeration and Diversity of Campylobacters and Bacteriophages Isolated During the Rearing Cycles of Free-Range and Organic Chickens. Appl. Environ. Microbiol. 2005, 71, 1259-1266. [CrossRef]

54. Jäckel, C.; Hammerl, J.A.; Rau, J.; Hertwig, S. A Multiplex Real-Time PCR for the Detection and Differentiation of Campylobacter Phages. PLoS ONE 2017, 12, e0190240. [CrossRef]

55. Atterbury, R.J.; Connerton, P.L.; Dodd, C.E.; Rees, C.E.; Connerton, I.F. Isolation and Characterization of Campylobacter Bacteriophages from Retail Poultry. Appl. Environ. Microbiol. 2003, 69, 4511-4518. [CrossRef]

56. Janez, N.; Kokosin, A.; Zaletel, E.; Vranac, T.; Kovac, J.; Vuckovic, D.; Smole Mozina, S.; Curin Serbec, V.; Zhang, Q.; Accetto, T.; et al. Identification and Characterisation of New Campylobacter Group III Phages of Animal Origin. FEMS Microbiol. Lett. 2014, 359, 64-71. [CrossRef] [PubMed]

57. Gencay, Y.E.; Sorensen, M.C.H.; Wenzel, C.Q.; Szymanski, C.M.; Brondsted, L. Phase Variable Expression of a Single Phage Receptor in Campylobacter jejuni NCTC 12662 Influences Sensitivity toward Several Diverse CPS-Dependent Phages. Front. Microbiol. 2018, 9, 82. [CrossRef] [PubMed]

58. Sorensen, M.C.; Gencay, Y.E.; Birk, T.; Baldvinsson, S.B.; Jäckel, C.; Hammerl, J.A.; Vegge, C.S.; Neve, H.; Brondsted, L. Primary Isolation Strain Determines Both Phage Type and Receptors Recognised by Campylobacter jejuni Bacteriophages. PLoS ONE 2015, 10, e0116287. [CrossRef] [PubMed]

59. Sorensen, M.C.; van Alphen, L.B.; Harboe, A.; Li, J.; Christensen, B.B.; Szymanski, C.M.; Brondsted, L. Bacteriophage F336 Recognizes the Capsular Phosphoramidate Modification of Campylobacter jejuni NCTC 11168. J. Bacteriol. 2011, 193, 6742-6749. [CrossRef]

60. Baldvinsson, S.B.; Sorensen, M.C.; Vegge, C.S.; Clokie, M.R.; Brondsted, L. Campylobacter jejuni Motility Is Required for Infection of the Flagellotropic Bacteriophage F341. Appl. Environ. Microbiol. 2014, 80, 7096-7106. [CrossRef] [PubMed]

61. Ng, L.K.; Stiles, M.E.; Taylor, D.E. Comparison of Basal Media for Culturing Campylobacter jejuni and Campylobacter coli. J. Clin. Microbiol. 1985, 21, 226-230.

62. Frost, J.A.; Kramer, J.M.; Gillanders, S.A. Phage Typing of Campylobacter jejuni and Campylobacter coli and Its Use as an Adjunct to Serotyping. Epidemiol. Infect. 1999, 123, 47-55. [CrossRef]

63. Sambrook, J.; Russell, D. Molecular Cloning: A Laboratory Manual; Cold Spring Harbor Laboratory Press: Cold Spring Harbor, NY, USA, 2001.

64. Fischer, S.; Kittler, S.; Klein, G.; Glünder, G. Microplate-Test for the Rapid Determination of BacteriophageSusceptibility of Campylobacter Isolates-Development and Validation. PLoS ONE 2013, 8, e53899. [CrossRef] [PubMed]

65. Rabinovitch, A.; Aviram, I.; Zaritsky, A. Bacterial Debris-an Ecological Mechanism for Coexistence of Bacteria and Their Viruses. J. Theor. Biol. 2003, 224, 377-383. [CrossRef]

66. Ackermann, H.W. Basic Phage Electron Microscopy. Methods Mol. Biol. 2009, 501, 113-126. [PubMed]

(C) 2019 by the authors. Licensee MDPI, Basel, Switzerland. This article is an open access article distributed under the terms and conditions of the Creative Commons Attribution (CC BY) license (http://creativecommons.org/licenses/by/4.0/). 